\title{
Preface: building trust in agricultural biotechnology partnerships
}

\author{
Calestous Juma
}

The 2011 famine in the Horn of Africa and the spectre of food price volatility have led to renewed interest in boosting local agricultural production in Africa. The surge in interest is occurring at a time when the impact of climate change on agriculture is becoming a central theme in policy discourse. These trends are inspiring the need to foster agricultural research as a way to raise productivity, diversify production and protect the environment [1].

It is widely held that long-term strategies to boost African agriculture will have to include the application of biotechnology. However, policy discussions on the role of biotechnology in African agriculture are marked by widespread distrust. The main sources of the distrust include concerns over the safety of genetically modified organisms (GMOs), fear of corporate control of the food sector, and uncertainty over the workings of publicprivate partnerships (PPPs).

The collection of papers in this special issue sheds light on why establishing trust among business, government, research institutions and the public is central to efforts to introduce agricultural biotechnology. The authors of these papers draw from experiences in Burkina Faso, Egypt, Kenya, Nigeria, South Africa, Tanzania, and Uganda to provide lessons for building effective partnerships based on trust. In addition, the papers contain real-life examples that show which PPPs have worked well, what undermined their evolution, and how their lessons could be shared to inform policy decisions and practical actions.

The papers are being published at a critical moment in the evolution of African agriculture. First, the continent is currently considering ways to become an important player in global agricultural production. The strategies being pursued by most countries in Africa include consideration of the role of agricultural biotechnology. By 2011, only three African countries (Burkina Faso, South Africa and Egypt) were commercially producing genetically modified (GM) crops. Recent decisions in Kenya to adopt a law that would approve the cultivation of GM crops, for example,

Harvard Kennedy School, Cambridge, Massachusetts, USA were accompanied by extensive debates that underscored the importance of building trust in the technology.

Second, discussions over the introduction of GM crops are occurring in the context of broader interest among African countries to put science and technology at the center of their development strategies. Much of this interest has been inspired by the dramatic benefits that mobile phones have brought to the continent. Two decades ago, mobile phones were viewed with the same suspicion and concerns over trust in related information technologies; such automation raised concerns over their implications for employment. The evolution of mobile technology in Africa now serves as a reference point in balancing between the benefits and risks of new technologies. These lessons are likely to lead to discussion on agricultural biotechnology.

Third, there is an increase in the number of PPPs seeking to foster the adoption of agricultural biotechnology. Those involved in these partnerships are seeking ways by which they can address the general anxiety arising from uncertainty over the structure, performance and benefits of PPPs. These actors will find valuable lessons in these papers on how to address such concerns.

These articles differ from much of the material available today in several important ways. First, they open the door for exploring the theoretical and practical implications of focusing on trust as a way to build confidence in new technologies. Second, they provide inspirational practical examples in each of the countries and institutions analyzed. Finally, they will be invaluable to a wider audience, including policy makers; donors; entrepreneurs; researchers; investors; and students of agricultural policy.

\section{Acknowledgements}

This article has been published as part of Agriculture \& Food Security Volume 1 Supplement 1, 2012: Fostering innovation through building trust: lessons from agricultural biotechnology partnerships in Africa. The full contents of the supplement are available online at http://www.agricultureandfoodsecurity. com/supplements/1/S1. Publication of this supplement was funded by the Sandra Rotman Centre at the University Health Network and the University of Toronto. The supplement was devised by the Sandra Rotman Centre. 


\section{Competing interests}

The author declares that they have no competing interests.

Published: 1 November 2012

\section{Reference}

1. Juma C: The New Harvest: Agricultural Innovation in Africa. Oxford University Press, New York; 2011.

doi:10.1186/2048-7010-1-S1-I1

Cite this article as: Juma: Preface: building trust in agricultural

biotechnology partnerships. Agriculture \& Food Security 2012 1(Suppl 1):11.

Submit your next manuscript to BioMed Central and take full advantage of:

- Convenient online submission

- Thorough peer review

- No space constraints or color figure charges

- Immediate publication on acceptance

- Inclusion in PubMed, CAS, Scopus and Google Scholar

- Research which is freely available for redistribution

Submit your manuscript at www.biomedcentral.com/submit 